\title{
LINGUISTICS VARIETIES : REGISTER IN ENGLISH FANFICTION KPOP "Miss Perfect Idol”
}

\author{
Reni Mulyani ${ }^{1}$, Lilis Suryani ${ }^{2}$ \\ ${ }^{1}$ IKIP Siliwangi \\ ${ }^{2}$ IKIP Siliwangi \\ ${ }^{1}$ arereniexo@gmail.com, ${ }^{2}$ suryani.lies3@gmail.com
}

\begin{abstract}
English fanfiction kpop was the stories who created by fans' to their idol by their imagination and used English in created the stories the reason was because kpopers / readers whole the world can read the stoeries and benefit for the author can improved their English skill especially in writing and vocabulary. The objectives of this study were to describe the linguistics form and the meaning of register used in English fanfiction kpop "Miss Perfect Idol" at www.asianfanfics.com website. The method used in this study was descriptive qualitative method. The data obtained from www.asianfanfics.com on 24th February 2018 . The researchers found out the linguistic forms in English fanfiction kpop "Miss Perfect Idol" there were noun (twenty five data of noun), adjective (six data of adjective), verb (five data of verb), interjection (two data of interjection), adverb of place (one data of adverb of place). In the meaning of register the reseachers found the high frequency data of register meaning that was contextual meaning, the data consist of 20 contextual meaning (51.3\%) and 19 lexical meaning (48.7\%). The contextual meaning more frequently appeared because there were a lot of new vocabularies created by kpopers and the author of fanfic and the vocabularies used in fanfiction.
\end{abstract}

Keywords: Linguistics Varieties, Register, English Fanfiction Kpop

\section{INTRODUCTION}

Fanfiction is an imaginative story created by fans to their idol. The characteristics, plot, of fanfiction based on fans's imagination to their idol. And hallyu wave or we called as kpop or kpopers means that kpop lovers is increasingly prevalent among teenagers in whole the world. Most of them truly creative in creating the story especially for their idol and in asianfanfics website is a forum that holds variuos fans' stories and in asianfanfics the stoeries using english, the reason is for all the fans or readers in the world can read it. But the problems is for non kpop fans there are many languages in the fanfic only understand by kpop fans it called register. Register is the special language that used in communities, it supported theory by (Wardhaugh 2006 : 52) registers are sets of language items associated with discrete occupational or social groups, such as surgeons, airline pilots, bank managers, sales, clerks, jazz fans, and pimps employ different registers. Based on the problem above the researchers take the research with entitled Linguistic Varieties : Register in English Fanfiction KPOP “Miss Perfect Idol”.

Fanfiction is fans fiction, the imaginative story who created by fans toward their idol based on their imagination. It supported by Barner $(2017: 126$ - 127) fanfiction is written within and for a community of fans, a "fandom" rather than by individual fans for a more widespread audience. Fanfiction also published online on privately owned fan websites, usually structured to support only one fandom, or on sites set up to host fanfiction is multiple fandoms, such as Fanfiction.Net 
and Archive of Our Own (AO3). Fanfictions writing created by the authors who were published online on fan websites can be read by the whole fans or reader in the world. Caroline $(2003: 4)$ in Argawati \& Suryani $(2017: 1)$ argues that writing is producing something in written form so that people can read, perform and use it.

The other expert which is a professor English in USA explained in her book with entitled "The Fanfiction Reader Folk Tales for The Digital Age” Coppa (2017:5) fanfiction is an essential part of the process by which these characters are expanded and made epic, loved by their fans into greatness. In process expanded of the characters author of fanfic must have the high creativity, Rockler (1998 : 6) in Mundriyah \& Parmawati (2016:4) stated creativity theory derives from two separate sources; the study of intelligence and the development of psychoanalysis. The relationship between intelligence theory and their imagination and hobby are the great combine to creating the unique characters. The researchers drawn conclusions that fanfiction is fiction story created by fans toward their idol and more expanded the characters and plot also published online based on the fandom. The famous English fanfiction kpop was "10080" created by exo-1 (EXO fans) published at www.asianfanfics.com on $5^{\text {th }}$ July 2015, because 10080 fanfic have the simple conflict but make the readers being emotional and love about the plot of fanfic "10080", and highly recommended to read there were English version and Indonesia version.

Hudson (1996 : 22) \& Ferguson (1972 : 30) in Wardhaugh (2006:25) agreed in defining variety in terms of a specific set of 'linguistic items' or 'human speech patterns' (presumably, sounds, words, grammatical features, etc.) which we can uniquely associate with some external factor (presumbly, a georaphical area or social group). Variety means that the language use depend on the speaker, speaker used variety on a georaphical area or social group. Dwiraharjo (1996:59-60) stated language variations or we called as linguistics varieties have idiolect types, dialects, various of languages, style, and register. The researchers just exposure dialects, style, and register.

\section{Idiolect}

Idiolect is variety of languages that individual characters, it means that the characteristics of one's speech is different from the speech of others Dwiraharjo (1996:59-60). The example of idiolek according to Unsiah \& Yuliati (2018:94) native speech from Malang is different with native speech from Medan.

\section{Dialect}

Dialect covers the word choices, syntatic ordering and all the grammatical choices a speaker could make (Stockwell, 2002:5). Dialect and language are differences because dialect is part of language, it supported theory by Stockwell (2002:5) "a language consists of one or many dialects all of which are more or less mutually intelligible to other speakers of the language. Wardhaugh (2006:43-51) in his book "An Introduction to Sociolinguistics" Fifth Edition classified dialect into regional dialect and social dialect.

\section{a. Regional Dialect}

Regional dialect is a dialect defined by geography (Valli \& Lucas, 2000:190). Regional variation in the way a language is spoken is likely to provide one of the easiest ways of 
observing variety of language. As you throughout a wide georaphical area in which a language is spoken, and particularly if that language has been spoken in that area for many hundreds of years, you are almost certain to notice differences in pronunciation, in the choices anf forms of words, and in syntax (Wardhaugh, 2006:43).

\section{b. Social Dialect}

Many experts defined social dialect but the researchers took two expert Yule \& Wardhaugh. Yule (2010:254) stated the study of social dialects has been mainly concerned will speakers in the town and cities. In the social study of dialect, it is social class that is mainly used to define groups of speakers as having something in common. The two main groups are generally identified as "middle class" who have more years of education and perform manual work, and "working class", those who have fewer years of education and perform manual work of some kind. So when we refer to "working class speech", we are talking about a social dialect. The term "upper" and "lower" are used to further subdivide the groups, mainly on an economic basis making "upper-middle-class-speech" another type of social dialect or sociolect. According to Wardhaugh (2006:49) "an immidiate problem is that of defining social group or social class giving proper weight to the various factors that can be used to determine social position, e.g occupation, place of residence, education, "new" versus "old" money, income, racial or ethnic origin, cultural background, caste, religion, and so on.

\section{Style}

Style is the way people talk in every single context for example : the way people talk in school, wedding ceremony, teaching in the classroom etc. Richards, et al (1995:277) stated that style is described as "variation in a person's speech or writing, style usually veries from casual to foemal according to the type of situation, the person(s) addressed, the location, the topic discussed. Five styles outlined by Joos (1959) in Mesthrie, et al (2009:93)

a. Intimate Style style involves a great deal of shared knowledge and background in a private conversation between equals. "Pillow talk" between partners is probably the best example of intimate style.

b. Casual Style, which is typical of informal speech between peers, includes ellipsis (or omission of certain grammatical elements) and slang between peers. (Joo's examples of ellipsis are Friend of mine saw it; Coffee's cold)

c. Consultative Style is the norm for informal conversation between strangers, Slang and ellipsis may not be used to the extent that they are used in casual speech with a friend; but informal markers of rapport like hmm, yes I know and informal linguistics elements like about, so thing and so on may still abound.

d. Formal Style is determined more by the setting than by the personal(s) interacting. Markers of formal English style include whom, may, I, for the purpose of and so on. Some, but not all, of the language assosiated with formal style is school-based.

e. Frozen Style is hyper-formal style designed to discourage friendly relations between participants. 


\section{Register}

Register is usually characterized entirely or almost so by vocabulary differences either by the use of particular words in a particular sense, register is a language variety viewed with respect to its context of use, register the word style and the grammar used by speakers and writers in the particular situation or in a particular type of writing, register a piece of writing speech or that is usually appropriate to the situation that it is used in using the example : the essay suddenly switches from a formal to an informal register, register on the other hand, refers to how an individual performs in particular contexts or social settings, the language style or register that people use varies according to purpose, situation and relationship (Trudgill 1983:101, Biber \& Finegan 1994:4, The Longman Dictionary of Comtemporary English 2001:1190 in Lochtman \& Kappel 2008:60, The Collin Cobuid Dictionary 2001:1297 in Lochtman \& Kappel 2008:60, Tagliamonte 2012:35, Coelho, 2004:190). Based on the definitions above the researchers concluded that register is the special language that used in the communities and only them understand such as register language in kpop community (e.g : oppa, noona, hyung, etc), doctor, soldier, teacher, and the other communities. And also register that can use by spoken language or written language based on the context.

\section{METHOD}

In conducting this research, the researchers used qualitative research method to describe and explained the meaning of the data gained also to get more detail information. Creswell (2012:236) in Aryana \& Apsari (2018:3) stated "Analyzing qualitative data requires understanding how to make sense of text and image, so that you can form answers to your research questions". The researchers add theory from Hamdi \& Bahruddin (2014:9) stated qualitative research was the research can explained and analyzed phenomena, events, social activities, beliefs, someone's perception, or groups toward something. The researchers took qualitative research method because the researchers understanding to analysis the data and to identify linguistic form that used in English Fanfiction Kpop "Miss Idol Perfect" also described the meaning of register word that used in English Fanfiction Kpop "Miss Idol Perfect". The instrument of this research was document analysis. In collected and analyzed the data the researchers used procedures as follows : First, the researchers obtained the data from www.asianfanfics.com on $24^{\text {th }}$ February 2018 as the source data. Second, the researchers read the data. Third, the researchers marked the word consist of the register in English fanfiction kpop. Fourth, the researchers classified the register English fanfiction kpop into linguistic form and classified the meaning of register into lexical meaning and contextual meaning. The last step the researchers put all the data in the table and analyzed the data.

\section{RESULTS AND DISCUSSION}

\section{Results}

Based on the analyzed conducted by researchers, the researchers described the result of register used in English fanfiction kpop "Miss Perfect Idol" through the table. The researchers described based on the linguistic forms, and the researchers found out the linguistic forms in english 
fanfiction kpop "Miss Perfect Idol" there were noun, adjective, verb, interjection, adverb of place.

\section{Table 1}

Linguistic Forms of Register used in English Fanfiction Kpop "Miss Perfect Idol”

\begin{tabular}{|c|c|c|c|c|}
\hline No & Linguistic Form & Register & $\Sigma$ Data & $\%$ \\
\hline 1. & Noun & $\begin{array}{l}\text { OC (original characters), } \\
\text { Rookie, Trainee, Maknae, } \\
\text { Hyung, Jeoneun, Samchon, } \\
\text { Oppa, Haneul-ssi, Bangtan } \\
\text { Sonyeodan, Sunbae, Appa, Nim, } \\
\text { Noona, Army, Eomma, Haneul- } \\
\text { ah Unnie, Sasaeng, Maknae line, } \\
\text { Hyung line Yeorobun, Shipper, } \\
\text { Visual, Ship Name }\end{array}$ & 25 & $64.1 \%$ \\
\hline 2. & Adjective & $\begin{array}{l}\text { Fluff, Romcom (Romance, } \\
\text { Comedy), Idol life, Jinja, } \\
\text { Joesonghamnida, Mianhae }\end{array}$ & 6 & $15.4 \%$ \\
\hline 3. & Verb & $\begin{array}{l}\text { Debut, Aegyo, Arraseo, } \\
\text { Annyeonghaseo, Hajima }\end{array}$ & 5 & $12.8 \%$ \\
\hline 4. & Interjection & Aigoo, $M w o$ & 2 & $5.1 \%$ \\
\hline 5. & Adverb of Place & Dorm & 1 & $2.5 \%$ \\
\hline \multicolumn{3}{|c|}{ Total of Register Word } & \multicolumn{2}{|c|}{39} \\
\hline
\end{tabular}

The table showed there were five of linguistics form found in English fanfiction kpop "Miss Perfect Idol" namely noun (twenty five data of noun), adjective (six data of adjective), verb (five data of verb), interjection (two data of interjection) and only one data of adverb of place. The highest frequency appeared of linguistics form was noun because noun had twenty five data (64.1\%), because the author mostly used the noun in the fanfiction "Miss Perfect Idol" such as Maknae, Hyung, Jeoneun, Samchon, Oppa.

Table 2

The Meaning Register of English Fanfiction Kpop "Miss Perfect Idol”

\begin{tabular}{clllc}
\hline \multirow{2}{*}{ No } & \multirow{2}{*}{ Register } & \multicolumn{2}{c}{ Meaning } & Type of Register \\
\cline { 3 - 5 } 1 & $\begin{array}{l}\text { OC (original } \\
\text { characters) }\end{array}$ & $\begin{array}{l}\text { Original Character (the character } \\
\text { created by author from their } \\
\text { imagination) }\end{array}$ & Contextual \\
\hline 2 & Rookie & $\begin{array}{l}\text { Newbie / nickname for them } \\
\text { (group / boyband / girlgroup) who } \\
\text { debut around 3 years or under 3 } \\
\text { years. }\end{array}$ & $\checkmark$ \\
\hline
\end{tabular}




\begin{tabular}{|c|c|c|c|c|}
\hline 3 & Trainee & $\begin{array}{l}\text { Appellation for k-idol wanna be } \\
\text { and still training. }\end{array}$ & $\checkmark$ & \\
\hline 4 & Maknae & $\begin{array}{l}\text { The youngest people in the family } \\
\text { / group }\end{array}$ & $\checkmark$ & \\
\hline 5 & Hyung & $\begin{array}{l}\text { Appellation from lil brother } \\
\text { toward big brother }\end{array}$ & $\checkmark$ & \\
\hline 6 & Jeoneun & I / Me (Formal) & $\checkmark$ & \\
\hline 7 & Samchon & Uncle & $\checkmark$ & \\
\hline 8 & Oppa & $\begin{array}{l}\text { Appellation from lil sister toward } \\
\text { big brother }\end{array}$ & $\checkmark$ & \\
\hline 9 & Haneul-ssi & $\begin{array}{l}\text { "ssi" this appellation usually used } \\
\text { toward the older or respected } \\
\text { person }\end{array}$ & & $\checkmark$ \\
\hline 10 & $\begin{array}{l}\text { Bangtan } \\
\text { Sonyeodan }\end{array}$ & $\begin{array}{l}\text { A boygroup from bighit } \\
\text { entertainment or we called as bts }\end{array}$ & & $\checkmark$ \\
\hline 11 & Sunbae & $\begin{array}{l}\text { Senior (in the college, in the } \\
\text { office) }\end{array}$ & $\checkmark$ & \\
\hline 12 & Appa & Father & $\checkmark$ & \\
\hline 13 & $\mathrm{Nim}$ & $\begin{array}{l}\text { Appellation formal, usually used } \\
\text { by siblings }\end{array}$ & & $\checkmark$ \\
\hline 14 & Noona & $\begin{array}{l}\text { Appellation from lil brother } \\
\text { toward big sister }\end{array}$ & $\checkmark$ & \\
\hline 15 & Army & Fans of BTS & & $\checkmark$ \\
\hline 16 & Eomma & Mother & $\checkmark$ & \\
\hline 17 & Haneul-ah & $\begin{array}{l}\text { "ah" this appellation usually used } \\
\text { for the same age or the younger } \\
\text { one, "ah" used by the names were } \\
\text { terminated by consonant letters }\end{array}$ & & $\checkmark$ \\
\hline 18 & Unnie & $\begin{array}{l}\begin{array}{l}\text { Appellation from big sister } \\
\text { toward lil sister }\end{array} \\
\end{array}$ & $\checkmark$ & \\
\hline 19 & Sasaeng & $\begin{array}{l}\text { A crazy fans who make a } \\
\text { something crazy to the their idol }\end{array}$ & & $\checkmark$ \\
\hline 20 & Maknae line & $\begin{array}{l}\text { Group of young members in a } \\
\text { boyband or girlband }\end{array}$ & & $\checkmark$ \\
\hline No & Register & Meaning & $\begin{array}{c}\text { Lexical } \\
\text { Meaning } \\
\end{array}$ & $\begin{array}{c}\text { Contextual } \\
\text { Meaning } \\
\end{array}$ \\
\hline 21 & Hyung line & $\begin{array}{l}\text { Group of old members in a } \\
\text { boyband }\end{array}$ & & $\checkmark$ \\
\hline 22 & Yeorobun & Audience & $\checkmark$ & \\
\hline 23 & Visual & $\begin{array}{l}\text { Center in the boygroup / girlgroup } \\
\text { usually the members who had } \\
\text { good looking or the most } \\
\text { beuatiful member / the most } \\
\text { handsome in their group }\end{array}$ & & $\checkmark$ \\
\hline 24 & Shipper & $\begin{array}{l}\text { The term person who pairs the } \\
\text { idols, such as ChanBaek } \\
\text { Chanyeol and Baekhyun Exo }\end{array}$ & & $\checkmark$ \\
\hline
\end{tabular}




\begin{tabular}{|c|c|c|c|c|}
\hline 25 & Ship Name & $\begin{array}{l}\text { The fans gave the abbreviation } \\
\text { name to their idols such as } \\
\text { BaekYeol Baekhyun Chanyeol } \\
\text { Exo, TaeJin Taehyung and Jin } \\
\text { BTS, etc }\end{array}$ & & $\bar{\checkmark}$ \\
\hline 26 & Fluff & $\begin{array}{l}\text { The genre of fanfic kpop that has } \\
\text { a romance story and happy ending }\end{array}$ & & $\checkmark$ \\
\hline 27 & $\begin{array}{l}\text { Romcom } \\
\text { (Romance, } \\
\text { Comedy) }\end{array}$ & $\begin{array}{l}\text { The story of fanfic about romance } \\
\text {, comedy }\end{array}$ & & $\checkmark$ \\
\hline 28 & Idol life & $\begin{array}{l}\text { The story of fanfic tell about k- } \\
\text { idol activity }\end{array}$ & & $\checkmark$ \\
\hline 29 & Jinja & Really & $\checkmark$ & \\
\hline 30 & $\begin{array}{l}\text { Joesonghamnid } \\
\text { a }\end{array}$ & I'm sorry (Formal) & $\checkmark$ & \\
\hline 31 & Mianhae & I'm sorry (Informal) & $\checkmark$ & \\
\hline 32 & Debut & $\begin{array}{l}\text { The first performance in the stage } \\
\text { of new boygroup / girlgroup }\end{array}$ & & $\checkmark$ \\
\hline 33 & Aegyo & $\begin{array}{l}\text { Did something cute in the front of } \\
\text { camera or in the front of fans }\end{array}$ & & $\checkmark$ \\
\hline 34 & Arraseo & Understand & $\checkmark$ & \\
\hline 35 & Annyeonghaseo & $\begin{array}{l}\text { Hello / hey / Good morning, it } \\
\text { means greet someone }\end{array}$ & $\checkmark$ & \\
\hline 36 & Hajima & Don't go & & $\checkmark$ \\
\hline 37 & Aigoo & $\begin{array}{l}\text { A frustration expression / } \\
\text { Ahhhhhhhhh! }\end{array}$ & & $\checkmark$ \\
\hline 38 & Mwo & What & $\checkmark$ & \\
\hline 39 & Dorm & The place that $\mathrm{k}$-idols living & $\checkmark$ & \\
\hline & & $\Sigma$ Data & 19 & 20 \\
\hline & & $\%$ & $48.7 \%$ & $51.3 \%$ \\
\hline
\end{tabular}

Based on the analyzed the data through the table, the researchers found the high frequency data of register meaning was contextual meaning. The data consist of 20 contextual meaning (51.3\%) and 19 lexical meaning (48.7\%). The contextual meaning more frequently appeared because there were a lot of new vocabularies created by kpopers and the author of fanfic and used in fanfictions. New vocabularies created by kpopers and the author of fanfic based on the situation and utterance, in line with Yendra (2018:26) contextual meaning is the meaning appeared causes relationship between utterance and context that used. Sarwiji (2008:72) in Widawati (2010:2) also argued that contextual meaning is the meaning of words based on the context. In general linguistic book Chaer (1994:290) in Widawati (2010:2) reveals that contextual meaning is the meaning of a word or the word that is in the context. The meaning of the context can also be related to the situation namely place, time, environment, use of the word

\section{Discussion}

English fanfiction kpop was the stories who created by fans' to their idol by their imagination and used English in created the stories the reason was because kpopers / readers whole the 
world can read the stoeries and benefit for the author can improved their English skill especially in writing and vocabulary. Based on the results mentioned above it showed that linguistic form mostly appeared was noun there were twenty five data and the high frequency of register meaning of english fanfiction kpop was contextual meaning.

In the first table showed the results there were five of linguistics form found in English fanfiction kpop "Miss Perfect Idol" namely noun (twenty five data of noun), adjective (six data of adjective), verb (five data of verb), interjection (two data of interjection) and only one data of adverb of place. The highest frequency appeared of linguistics form was noun because noun had twenty five data $(64.1 \%)$, because the author mostly used the noun in the fanfiction "Miss Perfect Idol" such as Maknae, Hyung, Jeoneun, Samchon, Oppa.

In the second table showed the results the high frequency data of register meaning was contextual meaning. The data consist of 20 contextual meaning (51.3\%) and 19 lexical meaning (48.7\%). The contextual meaning more frequently appeared because there were a lot of new vocabularies created by kpopers and the author of fanfic and used in fanfictions. New vocabularies created by kpopers and the author of fanfic based on the utterance and situation, in line with Yendra (2018:26) contextual meaning is the meaning appeared causes relationship between utterance and context that used. Sarwiji (2008:72) in Widawati (2010:2) also argued that contextual meaning is the meaning of words based on the context. In general linguistic book Chaer (1994:290) in Widawati (2010:2) reveals that contextual meaning is the meaning of a word or the word that is in the context, the meaning of the context can also be related to the situation namely place, time, environment, use of the word.

\section{CONCLUSION}

Based on the result of the data analyzed, the researchers concluded into the linguistics form of register and the meaning of register. In the linguistics form of register, the researchers found five the linguistic form there were noun (twenty five data of noun), adjective (six data of adjective), verb (five data of verb), interjection (two data of interjection), adverb of place (one data of adverb of place). The highest frequency appeared of linguistics form was noun because

noun had twenty five data (64.1\%), because the author mostly using the noun in the fanfiction "Miss Perfect Idol” such as Maknae, Hyung, Jeoneun, Samchon, Oppa, etc.

In the meaning of register the reseacher found the high frequency data of register meaning was contextual meaning. The data consist of 20 contextual meaning (51.3\%) and 19 lexical meaning (48.7\%). The contextual meaning more frequently appeared because there were a lot of new vocabulary created by kpopers and used in fanfictions. New vocabularies created by kpopers and the author of fanfic based on the situation and utterance, in line with Yendra (2018:26) contextual meaning is the meaning appeared causes relationship between utterance and context that used. Sarwiji (2008:72) in (Widawati, 2010:2) also argued that contextual meaning is the meaning of words based on the context. In general linguistic book Chaer reveals that contextual meaning is the meaning of a word or the word that is in the context. The meaning of the context 
can also be related to the situation namely place, time, environment, use of the word (1994:290) in Widawati (2010:2)

\section{ACKNOWLEDGMENTS}

Alhamdulillah rabil 'alamin the researchers express her highest gratitude to Allah subhanu wata'ala for blessing and opportunity to complete this article. The first reseacher gratefully thank to Mrs Lilis Suryani., M.Pd as a supervisor, Mr. Hendra Husnussalam, M.Hum and all the participants always support and give motivation and advice to finish this article. Also to IKIP SILIWANGI that gave us to publish this article. And gratefully thank for all the people that have been hard work and contribute to finish article perfectly.

\section{REFERENCES}

Argawati, N. O., \& Suryani, L. (2017). Teaching Writing Using Think-Pair-Share Viewed From Students' Level Of Risk-Taking. English Review, 6(1).

Aryana, S., \& Apsari, Y. (2018). Analysing Teacher's Difficulties In Teaching Listening.

ELTIN JOURNAL, Journal of English Language Teaching in Indonesia, 6(2), 100-106.

Barner, Ashley J. (2017). The Case for Fanfiction Exploring the Pleasures and Practices of a Maligned Craft. USA : McFarland \& Company, Inc.

Biber, Douglas., \& Finegan, Edward. (1994). Sociolinguistics Perspectives on Register. UK : Oxford University Press.

Coelho, Elizabeth. (2004). Adding English a Guide to Teaching in Multilingual Classroom. Canada : Pippin Publishing.

Coppa, Francesca. (2017). The Fanfiction Reader Folk Tales for The Digital Age. USA : University of Michigan Press.

Dwiraharjo, Maryono. (1996). Fungsi dan Bentuk Krama dalam Masyarakat Tutur Jawa :: Studi kasus di Kotamadya Surakarta (dissertation). Yogyakarta : Universitas Gajah Mada Hamdi, Asep Saepul., \& Bahruddin, E. (2014). Metode Penelitian Kuantitatif Aplikasi dalam Pendidikan. Yogyakarta : Deepublish.

Lochtman, Katja., \& Kappel, Jenny. (2008). The World a Global Village: Intercultural Competence in English Foreign Language Teaching. Belgium : Vulbpress

Mesthrie, Rajend., et al. (2009). Introductions Sociolinguitics (2 ${ }^{\text {nd }}$ Ed). British : Edinburgh University Press

Mundriyah, M., \& Parmawati, A. (2016). Using Think-Pair-Share (Tps) To Improve Students'writing Creativity (A Classroom Action Research In The Second Semester Students Of Stkip Siliwangi Bandung). P2m Stkip Siliwangi, 3(2), 84-91.

Richards, Jack., et al. (1995). Longman Dictionary of Language Teaching and Applied Linguistics $\left(4^{\text {th }} \mathrm{Ed}\right)$. Londong : Longman.

Stockwell, Peter. (2002). Sociolinguistics a Research Book for student. London : Routidge.

Tagliamonte, Sali A. (2012). Variations, Sociolinguistics, Change, Observation, Interpretation. United Kingdom : Wiley Blackwell.

Trudgill, Peter. (1983). Sociolinguistics An Introduction to Language and Society. Great Britain : Penguin Book. 
Unsiah, Frida, \& Yuliati, Ria. (2018). Pengantar Ilmu Linguistik. Malang : University Brawijaya Press.

Valli, Cleyton \& Lucas, Ceil. (2000). Linguistics of American Sign Language and Society. Washington DC : Gallaudet University Press

Wardhaugh, Ronald. (2006). An Introduction to Sociolinguistics ( $5^{\text {th }}$ Ed). United Kingdom : Blackwell Publishing

Widawati, Colli Widi. (2010, 10 ${ }^{\text {th }}$ May). Ragam Makna Makna Kontruksi, Makna Kontekstual dan Makna Konseptual. Retrieved 2019, $28^{\text {th }}$ April from https://colinawati.blog.uns.ac.id/2010/05/10/12

Yendra. (2018). Mengenal Ilmu Bahasa (Linguistik). Yogyakarta : Deepublish.

Yule, George. (2010). The study of language $\left(4^{\text {th }} E d\right)$. New York : Cambridge University Press. 